\title{
Assessment of Nutritional Potency and Pomological Traits in the Wild and Cultivated Varieties of Momordica charantia L. (Cucurbitaceae)
}

\author{
Salma Suhara Beevy and Noor Muhammed Haseena Bai
}

\author{
Department of Botany, University of Kerala Kariavattom, Thiruvananthapuram \\ 695 508, India
}

\begin{abstract}
Nutrient composition in the fruits of cultivated and wild varieties of $M$. charantia viz, M.charantia var. charantia and var. muricata were evaluated to prioritize the wild accessions suitable for crop improvement programme. The nutritive value of the varieties were assessed in terms of the quantity of proteins, carbohydrate, vitamins, total sugar, reducing and non-reducing sugar and minerals like $\mathrm{Na}, \mathrm{Ca}, \mathrm{Mg}, \mathrm{Mn}, \mathrm{Fe}, \mathrm{Cu}$ and $\mathrm{Zn}$. The wild variety was found superior than the cultivar in terms of their nutrient content. The study recognized $\mathrm{MC12}$, as the elite germplasm with highest concentration of Vit. E, B2, Cu and $\mathrm{Ca}$ and the accession MC10 as a rich source of carbohydrate, non-reducing sugar and Vit. B1. The accessions MC2, MC7, and MC15 were superior having higher concentration of protein, Vit. C and reducing sugar respectively. Correlation analysis was carried out to determine the relationship between fruit traits and nutrient composition. UPGMA dendrogram analysis suggests that the nutritional variation in the accessions was not determined by the fruit and seed morphology. However, a direct relationship between the nutrient contents and the fruit traits viz, fruit weight, length and fruit diameter was observed. The study recommends the accessions like MC12, MC7, MC10, and MC15 with high nutrient composition for bitter gourd breeding programme. The study emphasizes the conservation of the wild species, the rich sources of nutrients for crop improvement programme.
\end{abstract}

Key words: fruit traits, intra specific, M. charantia var.charantia, M.charantia var.muricata, nutrient contents.

\section{INTRODUCTION}

Momordica charantia L.commonly known as bitter gourd, or balsam pear or bitter melon belonging to the family Cucurbitaceae is the most widely cultivated species of the genus Momordica. The species has many uses; the immature fruit,young stems, leaves and flowers are taken as vegetable, primarily in Asia and particularly in India (Reyceet al. 1994).M. charantia includes both the wild and cultivated varieties, and are distinguished by their nature of leaves and fruits (Decker-Walters, 1999; Behara et al., 2006). The species possessess two varieties viz: variety charantia which produces large fusiform fruits and variety muricata(wild)with small and round fruits(Chakravathy,1990). The wild species offers great resources for breeding of the cultivated bitter gourd for the desirable edible or qualitative traits such as non bitterness, tolerance to abiotic stresses and resistance to several insect pests. According to a FAO report, at least one billion people are thought to use wild plants in their diet and for medicines. In most of the report it was emphasized that nutritionally, these wild plants could be comparable to or even sometimes superior to the 
introduced cultivars.

Earlier researchers have evaluated the nutritional composition of different types of wild plants and suggested their significance as source of nutrients (Freiberger et al.,(1998), Markovic et al. (1996),Mahapatra et al. (2012) and Mahadkar et al. (2012). Recent studies on agro-pastoral societies in Africa indicated that these wild plant resources play a significant role in nutrition, food security, and income generation (Edmons and Chweya1995). Aberoumand and Deokula (2009) have also suggested the incorporation of edible wild and semi cultivated plant resources to nutritionally marginal populations in developing countries. Variations in the nutritional content and morphological traits of fruits at inter specific level have been demonstrated in plant community (Debussche et al.,1987; Herrera,1987; and Corlett, 1996), whereas reports on intra specific variations in the quantity of nutrients particularly in the wild fruits are rare (Jordano, 1984 and Izhaki et al. (2002).

Bakare et al. (2000), Santhi et al. (2011) and Ullah et al. (2011) have evaluated the nutrient and phytochemical constituents in M.charantia and identified its immense value as a biomedicine. Although the general biochemical composition of immature fruits of M.charantia is similar to other cucurbits, bitter gourd possessess comparatively high concentration of nutrients (Miniraj et al. 1993, Desai and Musmade, 1998 and Behera 2004).

However, considerable variations were reported in the nutrient contents in the cultivars of M.charantia (Wills et al., 1984; Kale et al., 1991; Yuwai et al., 1991; Bakare et al. 2010 and Ullah et al.2011). Studies on the nutritional constituents in M.dioica were reported by Singh et al., (2009) and Aberoumand (2010). According to Bakareet al., (2010) the future breeding and genetic emphasis in bitter gourd improvement should be placed on the development of nutritious, high yeilding cultivars. But reports on the nutritional analysis in the wild varieties of M.charantia, a source of germplasm for crop improvement, are lacking except that of Ullah et al (2011). In the present investigation, a comparative analysis of the wild and cultivated varieties of M.charantia was carried out to assess the intra specific variability in nutritional composition in relation to the cultivars. Correlation between the fruit morphology and the nutrient composition in the wild was also attempted to analyse the intra specific relationship.

\section{MATERIALS AND METHODS}

Two accessions of the cultivated variety, M.charantia var.charantia (MC1 \& MC2) and thirteen accessions of the wild variety M.charantia var.muricata (MC3-MC15) collected from various parts of the state of Kerala, Tamil Nadu and Karnataka were analysed in the present investigation. The characteristics of fruits and seeds of the accessions are presented in Table 1.

Table 1. Accessions of the varieties of $M$. charantia and their characteristics.

\begin{tabular}{|c|c|c|c|c|c|c|c|c|}
\hline $\begin{array}{l}\text { Species - } \\
\text { accessions }\end{array}$ & Code & $\begin{array}{l}\text { Collection } \\
\text { place }\end{array}$ & $\begin{array}{l}\text { Fruit } \\
\text { shape }\end{array}$ & $\begin{array}{l}\text { Nature of } \\
\text { tubercle }\end{array}$ & $\begin{array}{l}\text { Density of } \\
\text { tubercle }\end{array}$ & $\begin{array}{l}\text { Seed } \\
\text { color }\end{array}$ & Seed shape & $\begin{array}{l}\text { Extent of seed } \\
\text { sculpture }\end{array}$ \\
\hline $\begin{array}{l}\text { M.charantia } \\
\text { var.charantia }\end{array}$ & MC1 & $\begin{array}{l}\text { Kerala } \\
\text { Agricultural } \\
\text { University }\end{array}$ & Elliptical & $\begin{array}{l}\text { Raised \& } \\
\text { blunt }\end{array}$ & Dense & Straw & $\begin{array}{l}\text { Broad } \\
\text { rectangular }\end{array}$ & $\begin{array}{l}\text { Markedly } \\
\text { sculptured }\end{array}$ \\
\hline " & MC2 & $\begin{array}{l}\text { Kulathupuzha } \\
\text { (Trivandrum) }\end{array}$ & Elliptical & $\begin{array}{l}\text { Raised \& } \\
\text { blunt }\end{array}$ & Dense & Straw & $\begin{array}{l}\text { Broad } \\
\text { rectangular }\end{array}$ & $\begin{array}{l}\text { Markedly } \\
\text { sculptured }\end{array}$ \\
\hline $\begin{array}{l}\text { M.charantia } \\
\text { var. muricata }\end{array}$ & MC3 & $\begin{array}{l}\text { Karaikal } \\
\text { (Tamil Nadu) }\end{array}$ & Cylindrical & $\begin{array}{l}\text { Raised \& } \\
\text { pointed }\end{array}$ & Sparse & Straw & $\begin{array}{l}\text { Broad } \\
\text { rectangular }\end{array}$ & $\begin{array}{l}\text { Markedly } \\
\text { sculptured }\end{array}$ \\
\hline " & MC4 & $\begin{array}{l}\text { Aryankavu } \\
\text { (Kollam) }\end{array}$ & Rhomboid & $\begin{array}{l}\text { Raised \& } \\
\text { blunt }\end{array}$ & Sparse & $\begin{array}{l}\text { Black \& } \\
\text { brown } \\
\text { patched }\end{array}$ & $\begin{array}{l}\text { Broad } \\
\text { rectangular }\end{array}$ & $\begin{array}{l}\text { Markedly } \\
\text { sculptured }\end{array}$ \\
\hline “ & MC5 & $\begin{array}{l}\text { Achankovil } \\
\text { (Kollam) }\end{array}$ & Globular & $\begin{array}{l}\text { Raised \& } \\
\text { blunt }\end{array}$ & Medium & Straw & $\begin{array}{l}\text { Broad } \\
\text { rectangular }\end{array}$ & $\begin{array}{l}\text { Markedly } \\
\text { sculptured }\end{array}$ \\
\hline
\end{tabular}


Table 1. Continuation.

\begin{tabular}{|c|c|c|c|c|c|c|c|c|}
\hline $\begin{array}{l}\text { Species - } \\
\text { accessions }\end{array}$ & Code & Collection Place & $\begin{array}{l}\text { Fruit } \\
\text { Shape }\end{array}$ & $\begin{array}{l}\text { Nature of } \\
\text { Tubercle }\end{array}$ & $\begin{array}{l}\text { Density of } \\
\text { Tubercle }\end{array}$ & $\begin{array}{l}\text { Seed } \\
\text { Color }\end{array}$ & $\begin{array}{l}\text { Seed } \\
\text { Shape }\end{array}$ & $\begin{array}{l}\text { Extent of Seed } \\
\text { Sculpture }\end{array}$ \\
\hline $\begin{array}{l}\text { M.charantia } \\
\text { var. muricata }\end{array}$ & MC6 & $\begin{array}{l}\text { Kulathupuzha } \\
\text { (Trivandrum) }\end{array}$ & Rhomboid & $\begin{array}{l}\text { Raised \& } \\
\text { blunt }\end{array}$ & Medium & $\begin{array}{l}\text { Black \& } \\
\text { brown } \\
\text { patched }\end{array}$ & $\begin{array}{l}\text { Broad } \\
\text { rectangular }\end{array}$ & $\begin{array}{l}\text { Markedly } \\
\text { sculptured }\end{array}$ \\
\hline “ & MC7 & $\begin{array}{l}\text { Neyyardam } \\
\text { (Trivandrum) }\end{array}$ & Globular & $\begin{array}{l}\text { Soft \& } \\
\text { flat }\end{array}$ & Sparse & Straw & $\begin{array}{l}\text { Broad } \\
\text { rectangular }\end{array}$ & $\begin{array}{l}\text { Markedly } \\
\text { sculptured }\end{array}$ \\
\hline “ & MC8 & $\begin{array}{l}\text { Sulthan Battery } \\
\text { (Wayanad) }\end{array}$ & Disc & $\begin{array}{l}\text { Soft \& } \\
\text { flat }\end{array}$ & Sparse & Straw & $\begin{array}{l}\text { Broad } \\
\text { rectangular }\end{array}$ & $\begin{array}{l}\text { Markedly } \\
\text { sculptured }\end{array}$ \\
\hline “ & MC9 & Pathanamthitta & Rhomboid & $\begin{array}{l}\text { Raised \& } \\
\text { blunt }\end{array}$ & Medium & Straw & $\begin{array}{l}\text { Broad } \\
\text { rectangular }\end{array}$ & $\begin{array}{l}\text { Markedly } \\
\text { sculptured }\end{array}$ \\
\hline “ & MC10 & $\begin{array}{l}\text { Manipal } \\
\text { (Karnataka) }\end{array}$ & Others & $\begin{array}{l}\text { Raised \& } \\
\text { blunt }\end{array}$ & Medium & $\begin{array}{l}\text { Brownis } \\
\mathrm{h} \tan \end{array}$ & $\begin{array}{l}\text { Narrow } \\
\text { rectangular }\end{array}$ & $\begin{array}{l}\text { Feebly } \\
\text { sculptured }\end{array}$ \\
\hline “ & MC11 & Palakkad & Oblong & $\begin{array}{l}\text { Raised \& } \\
\text { pointed }\end{array}$ & Sparse & $\begin{array}{l}\text { Whitish } \\
\text { brown }\end{array}$ & $\begin{array}{l}\text { Narrow } \\
\text { rectangular }\end{array}$ & $\begin{array}{l}\text { Feebly } \\
\text { sculptured }\end{array}$ \\
\hline “ & MC12 & $\begin{array}{l}\text { Kuthirankayatto } \\
\mathrm{m} \text { (Thrissur) }\end{array}$ & Globular & $\begin{array}{l}\text { Soft \& } \\
\text { flat }\end{array}$ & Sparse & White & $\begin{array}{l}\text { Narrow } \\
\text { rectangular }\end{array}$ & $\begin{array}{l}\text { Feebly } \\
\text { sculptured }\end{array}$ \\
\hline “ & MC13 & Puthuvayal & Disc & $\begin{array}{l}\text { Soft } \\
\& \text { flat }\end{array}$ & Sparse & $\begin{array}{l}\text { Whitish } \\
\text { brown }\end{array}$ & $\begin{array}{l}\text { Narrow } \\
\text { rectangular }\end{array}$ & $\begin{array}{l}\text { Feebly } \\
\text { sculptured }\end{array}$ \\
\hline “ & MC14 & Chennai & Disc & $\begin{array}{l}\text { Raised \& } \\
\text { pointed }\end{array}$ & Sparse & White & $\begin{array}{l}\text { Narrow } \\
\text { rectangular }\end{array}$ & $\begin{array}{l}\text { Feebly } \\
\text { sculptured }\end{array}$ \\
\hline “ & MC15 & Thrissur & Cylindrical & $\begin{array}{l}\text { Raised \& } \\
\text { pointed }\end{array}$ & Sparse & $\begin{array}{l}\text { Whitish } \\
\text { brown }\end{array}$ & $\begin{array}{l}\text { Narrow } \\
\text { rectangular }\end{array}$ & $\begin{array}{l}\text { Feebly } \\
\text { sculptured }\end{array}$ \\
\hline
\end{tabular}

\section{Pomological and NutritionalEvaluation}

The accessions of the wild variety, $M$.charantia var. muricata, have shown variations with regard to the shape of the fruits, nature and density of tubercles, and the colour, shape and surface ornamentation of seeds. Pomological traits were evaluated using the descriptors proposed by Joseph and Antony (2010). Healthy and disinfected fresh fruits of all the accessions without seeds were used for the analysis after these were properly washed with water and dried by blotting.

Standard methods were followed for analyzing the nutrient parameters like total carbohydrate (1962), total sugar (Rangana 1979), protein (Lowry et al 1951) and reducing sugar(Miller 1972). The quantity of non-reducing sugar was calculated by subtracting the amount of reducing sugar from that of the total sugars. The quantity of vitamins like thiamine, riboflavin, tocopherol (Okwu, 2005) and ascorbic acid(Harris and Ray 1935) was determined. Elemental analysis included the determination of $\mathrm{Na}, \mathrm{Ca}, \mathrm{Mg}, \mathrm{Fe}, \mathrm{Mn}, \mathrm{Zn}$, and $\mathrm{Cu}$. For element quantification, $0.5 \mathrm{~g}$ of fine powdered sample of each fruit was digested following wet digestion procedure using conc. $\mathrm{HNO}_{3}$ and $\mathrm{HClO}_{3}$ and filtered through Whatmann 42 filter paper and the filtrate was analysed using Atomic Absorption Spectrophotometer (Vogel, 1962).

\section{Statistical Analysis}

One Way ANOVA was used to determine the significant variations in the nutritional composition between the accessions. The pomological traits and nutrient composition in the wild and cultivated varieties of M.charantia were subjected to PCA and Pearson Correlation study to determine the relationships between nutrient composition and pomological traits. Fruit morphological traits such as fruit weight, fruit diameter, fruit length and clutch size (number of seeds / fruit) were considered in the correlation analysis. Principal Component Analysis was carried out to detect the most variable nutrient parameters. Cluster analysis of the preliminary nutritional data was also performed using the Unweighted Pair group Method with Arithmetic Averages (UPGMA) to examine the similarity and dissimilarity at the intra specific level using NTSYS software package. 


\section{RESULTS AND DISCUSSION}

\section{Pomological and Nutritional Evaluation}

The wild accessions differed markedly in the shape of the fruits and seeds, nature and density of tubercles on the fruit surface and in the seed surface characteristics(Table 1). However, no variation was observed in the cultivated variety. Analysis of the nutrient composition in the accessions of the wild and cultivated varieties of M.charantia (Table $2 \&$ Fig. I ) revealed higher amount of carbohydrate, reducing sugar, non-reducing sugar, protein and vitamin content in the wild varieties of M.charantia compared to that of the cultivated variety. However, the commercially released cultivated variety MC1 exhibited very low percentage of protein, total sugar, reducing sugar, vitamin B1, Ca, and Fe. Out of the 13 wild accessions, MC12 from Thrissur district, Kerala had the highest concentration of Vit. E, B2,Cu and Ca. The wild accession MC10 had higher concentration of carbohydrate, non-educing sugar and Vit. B1. The accessions MC2, MC7, MC15 were characterized by higher concentration of protein, of Vit. C and reducing sugar, respectively.

The quantity of carbohydrate, reducing sugar, non-reducing sugar, protein and vitamin content in the fruits of the cultivated and wild varieties of M.charantia (MC1 MC15) shown in Table 2 revealed that the accessions of the wild variety were superior in nutritional composition than the cultivated ones. However, significant variations were observed among the varieties in the content of the nutrients present in them. Data on the analysis of elements including $\mathrm{Cu}, \mathrm{Ca}, \mathrm{Fe}, \mathrm{Mn}, \mathrm{Mg}, \mathrm{Na}$, and $\mathrm{Zn}$ are shown (Fig.I). Analysis of the nutrient composition (Table 2 \& Fig..I ) revealed higher amount of carbohydrate, reducing sugar, non-reducing sugar, protein and vitamin content in the wild varieties of M.charantia compared to that of the cultivated variety. However, the commercially released cultivated variety $\mathrm{MC1}$, exhibited very low percentage of protein, total sugar, reducing sugar, vitamin B1, Ca, and Fe. Out of the 13 wild accessions, MC12 from Thrissur district, Kerala had the highest concentration of Vit. E, B2, Cu, and Ca. The wild accession MC10 had higher concentration of carbohydrate, non-reducing sugar and Vit. B1. The accessions MC2, MC7, MC15 were characterized by higher concentration of protein, of Vit. C, and reducing sugar respectively. The micronutrients were appreciably high in the wild accessions especially in MC13, MC14, and MC8. Ullah et al. (2011) recorded the highest amount of total sugar, proteins, and $\mathrm{Cu}$ in the wild variety muricata from Bangladesh. Better nutritional value of some wild fruits compared to the cultivated ones was identified by Eromosele (1991) and Murugkar and Subbulakshmi (2005).

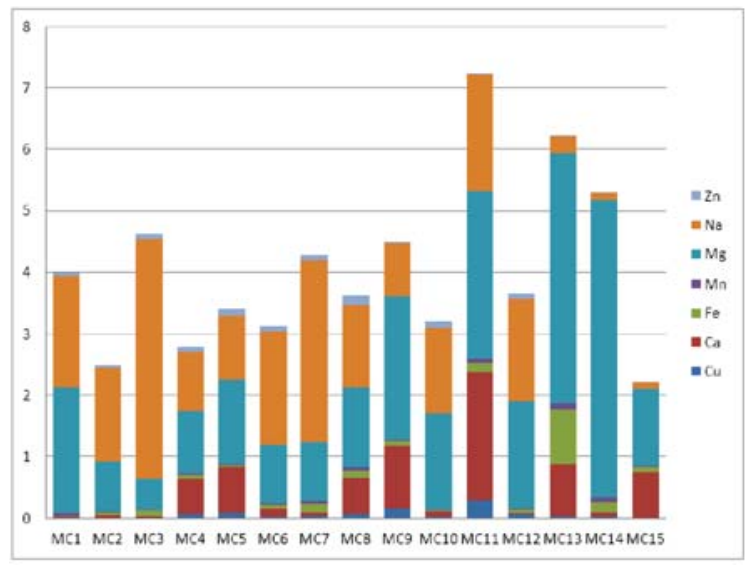

Fig. 1. Elemental Analysis in the Accessions of M.charantia (mg/100gm) MC 1\& MC2 - M.charantia var. charantia accessions Mc3 MC15 - M.charantia var. muricata accessions 


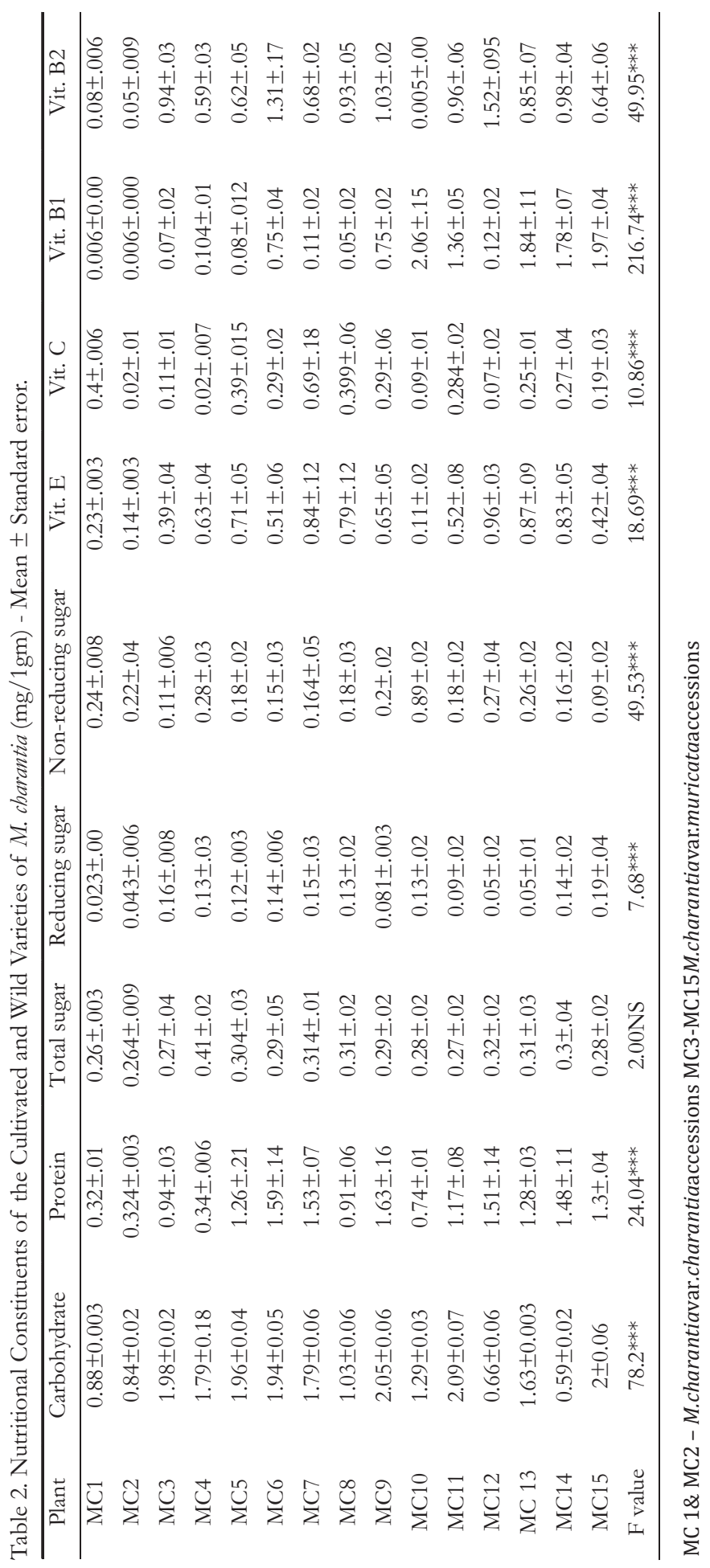


The present study revealed that the accessionMC7, with considerably rich vitamin $\mathrm{C}$ content $(69 \mathrm{mg} / 100 \mathrm{gm})$, can be used in the bitter gourd breeding programme. According to Dey et al. (2005-2006), breeding for nutritional/medicinal quality of bitter gourd typically emphasizes accessions with relatively high Vit. C content. The present study does not recommend the selection of MC2 with very low Vit.C. content. The study also revealed the superiority of the accession $\mathrm{MC12}$, and it recommends the variety for hybridization programme. Decrease in the nutritional quality in the cultivated variety, $M$. charantia var.charantia, may be due to the inappropriate method of selection during domestication, where importance was given to those plants having larger plant parts like larger fruits. The study is not in agreement with the view proposed by Kendrick et al. (2004) that the nutritional quality of M.charantia decreased as a result of domestication.

\section{Statistical Analysis}

Pearson correlation study of fruit morphological traits and nutritional parameters of the accessions of the wild variety, M.charantia var. muricata, revealed significant negative correlation between the nutrients like protein, Vit. C, Vit. E, and Vit. B2 and fruit characteristics like fruit weight, diameter, length and clutch size, i.e., number of seeds / fruit at 0.05 level (Table $3 \mathrm{a} \& 3 \mathrm{~b}$ ). However, a positive correlation was observed between fruit length and clutch size. Negative correlation was also existed between the quantity of minerals like $\mathrm{Cu}, \mathrm{Ca}$, and different fruit charcters. It was observed that the carbohydrate content and fruit traits were positively correlated while reducing sugar showed significant positive correlation only with fruit size. Positive correlation was also noted between total sugar and weight and diameter of the fruits and not with fruit length. No significant correlation was observed between fruit length and quantity of Fe. Positive and negative correlation also existed between some of the nutritional parameters (eg: $\mathrm{Mg}, \mathrm{Zn}, \mathrm{Fe}, \mathrm{Na}$ ) with the fruit traits at 0.01 and 0.05 levels. Principal Component Analysis (Table 4) revealed that the quantity of carbohydrate, $\mathrm{Mg}, \mathrm{Na}$, and protein content are the highly loaded characters in the first two principal axis with the percentage of variance 65.59 and 15.62, respectively. Variations were observed at the intra specific levels in M.charantia var. muricata during the investigation which may be due to the influence of those characters.

Table 3a. Correlation Between Pomological and Nutritional Value of M.charantia var. muricata Accessions.

\begin{tabular}{|c|c|c|c|c|c|c|c|c|c|c|}
\hline & $\mathrm{Na}$ & $\begin{array}{l}\text { No: } \\
\text { seeds }\end{array}$ & $\begin{array}{l}\text { NR. } \\
\text { Sugar }\end{array}$ & PTN & $\begin{array}{l}\text { RD. } \\
\text { Sugar }\end{array}$ & T.Sugar & Vit B1 & Vit B2 & Vit E & $\mathrm{Zn}$ \\
\hline $\mathrm{Na}$ & 1 & & & & & & & & & \\
\hline $\begin{array}{l}\text { No: } \\
\text { seeds }\end{array}$ & -0.14 & 1 & & & & & & & & \\
\hline $\begin{array}{l}\text { NR. } \\
\text { Sugar }\end{array}$ & $-0.35^{*}$ & $0.24^{*}$ & 1 & & & & & & & \\
\hline PTN & -0.05 & $-0.56 * *$ & $-0.27 * *$ & 1 & & & & & & \\
\hline $\begin{array}{l}\text { RD. } \\
\text { Sugar }\end{array}$ & 0.17 & 0.13 & $0.29 * *$ & $0.21^{*}$ & 1 & & & & & \\
\hline T.Sugar & -0.17 & 0.02 & -0.18 & -0.47 & -0.14 & 1 & & & & \\
\hline Vit B1 & $-0.59 * *$ & 0.15 & $0.62^{* *}$ & 0.09 & 0.20 & $-0.41 * *$ & 1 & & & \\
\hline Vit B2 & 0.15 & $-0.42 * *$ & $-0.63 * *$ & $0.57 * *$ & $0.389 * *$ & -0.05 & $-0.34 * *$ & 1 & & \\
\hline Vit E & -0.15 & $0.57 * *$ & $-0.62^{* *}$ & $0.43^{* *}$ & $-0.48^{* *}$ & $0.39 * *$ & $-0.37 * *$ & $0.59 * *$ & 1 & \\
\hline $\mathrm{Zn}$ & $0.33^{* *}$ & $0.23^{*}$ & 0.08 & $-0.44 * *$ & $0.25^{*}$ & 0.09 & $-0.37 * *$ & $-0.396 * *$ & $-0.25^{*}$ & 1 \\
\hline
\end{tabular}

*Correlation is significant at the 0.05 level (2-tailed).

$* *$ Correlation is significant at the 0.01 level (2-tailed).

F.L. - Fruit Length, F.W. - Fruit Weight, F.D. - Fruit diameter, N.R.-sugar - Non-reducing sugar, PTN-

Protein, R.D.sugar - Reducing sugar, T.sugar - Total sugar 
Table 3b. Correlation Between Pomological and Nutritional Value of M.charantia var. muricata Accessions.

\begin{tabular}{|c|c|c|c|c|c|c|c|c|c|c|}
\hline & Vit C & $\mathrm{Ca}$ & $\mathrm{CHO}$ & $\mathrm{Cu}$ & $\mathrm{Fe}$ & F.W & F.D & F.L & $\mathrm{Mg}$ & $\mathrm{Mn}$ \\
\hline Vit C & 1 & & & & & & & & & \\
\hline $\mathrm{Ca}$ & $-0.28^{* *}$ & 1 & & & & & & & & \\
\hline $\mathrm{CHO}$ & -0.07 & $-0.42^{* *}$ & 1 & & & & & & & \\
\hline $\mathrm{Cu}$ & -0.17 & $0.88^{* *}$ & $-0.44 * *$ & 1 & & & & & & \\
\hline $\mathrm{Fe}$ & 0.04 & $0.198 *$ & $-0.22^{*}$ & -0.05 & 1 & & & & & \\
\hline F.W & $-0.47 * *$ & $-0.33 * *$ & $0.53 * *$ & $-0.33 * *$ & $-0.34 * *$ & 1 & & & & \\
\hline F.D & $-0.37 * *$ & $-0.30 * *$ & $0.47 * *$ & $-0.27 * *$ & $-0.32^{* *}$ & $0.77^{* *}$ & 1 & & & \\
\hline F.L & $-0.51 * *$ & $-0.36^{* *}$ & $0.46^{* *}$ & $-0.49 * *$ & -0.01 & $0.51^{* *}$ & $0.41 * *$ & 1 & & \\
\hline $\mathrm{Mg}$ & -0.08 & $0.25^{*}$ & $-0.54 * *$ & 0.19 & $-0.58^{* *}$ & $-0.52^{* *}$ & $-0.47^{* *}$ & -0.13 & 1 & \\
\hline Mn & 0.12 & $0.37 * *$ & $-0.7^{* *}$ & $0.25^{*}$ & $0.79 * *$ & $-0.60 * *$ & $-0.46^{* *}$ & $-.26 * *$ & $0.72 * *$ & 1 \\
\hline
\end{tabular}

${ }^{*}$ Correlation is significant at the 0.05 level (2-tailed). ${ }^{* *}$ Correlation is significant at the 0.01 level (2-tailed).

F.L-Fruit Length, F.W-Fruit Weight, ,F.D- Fruit diameter

Table 4. Highly Loaded Characters in Principal Component Analysis.

\begin{tabular}{lcc}
\hline \multicolumn{1}{c}{ Characters } & Principal Axis 1 & Principal Axis 2 \\
\hline $\mathrm{CHO}$ & & 0.070 \\
$\mathrm{Mg}$ & 1.504 & -0.788 \\
$\mathrm{Na}$ & 1.497 & 1.101 \\
Protein & 1.292 & -0.107 \\
Eigen values & 0.645 & 2.344 \\
Percentage & 9.839 & 15.624 \\
Cumulative percentage & 65.593 & 81.217 \\
\hline
\end{tabular}

The dendrogram constructed based on the nutrient composition (Fig. 2) revealed two principal clusters at an Euclidean distance of 0.68. Each principal cluster had two subclusters with euclidean distances $0.62,0.68$ for the first and 0.40 and 0.52 for the second subcluster, respectively. The wild accessions MC13, MC14, and MC15 were clustered in the second subcluster at an euclidean distance of 0.5 . The dendrogram did not differentiate the wild and cultivated taxa. Clustering of the wild and cultivated accessions together in the first principal cluster suggest that they possessed more or less the same type of nutritional components. However, the accessions differed in the quantity of nutrients. It was observed that the cluster distance between the wild accessions MC 8 and MC5, MC 6 and MC12, MC 7 and MC 3, and MC14 and MC 13 was minimum based on nutritional value. The grouping of MC13 and MC 14 together in the second cluster may be due to the presence of high quantity of micronutrients in those accessions. Similarity based on the nutrient characters was evident from the grouping of the wild accessions MC8 and MC5 (0.22), MC6 and MC12 (0.28), MC7 and MC3 (0.30) and the two cultivated accessions MC1 and MC2 (0.27) The least cluster distances observed in those cited above revealed that they are closely related based on the nutrient characters. The study noticed (Table 2) that among the cultivated variety, the cultivar Preethi, procured from Kerala Agricultural University had comparatively more nutrient contents than the land race collected from Kulathupuzha and that may be due to the appropriate agricultural practices employed to the cultivated species.

UPGMA analysis revealed that the clustering of wild accessions was not in accordance with fruit and seed characters, i.e., the accessions with markedly sculptured seeds (MC3-MC9) and feebly sculptured seeds(MC10- MC15) were grouped intermittently. It indicates that the seed characters have no role in determining the nutritional quality. However, clustering of the three accessions MC13,14\&15 together in a group revealed the interrelationship of the taxa. Scatter analysis based on nutrient characters (Fig. 3) also supported the grouping of wild accessions and the two cultivated accessions as in the 
UPGMA dendrogram. Occurrence of wild accessions in independent groups in different axes in the scatter plot points out the nutritional variation, and that may be due to genetic and environmental interaction. Obeso and Herrera (1994) suggested that the variations in nutritional characters among species might be due to the consequences of genetic and environmental factors.

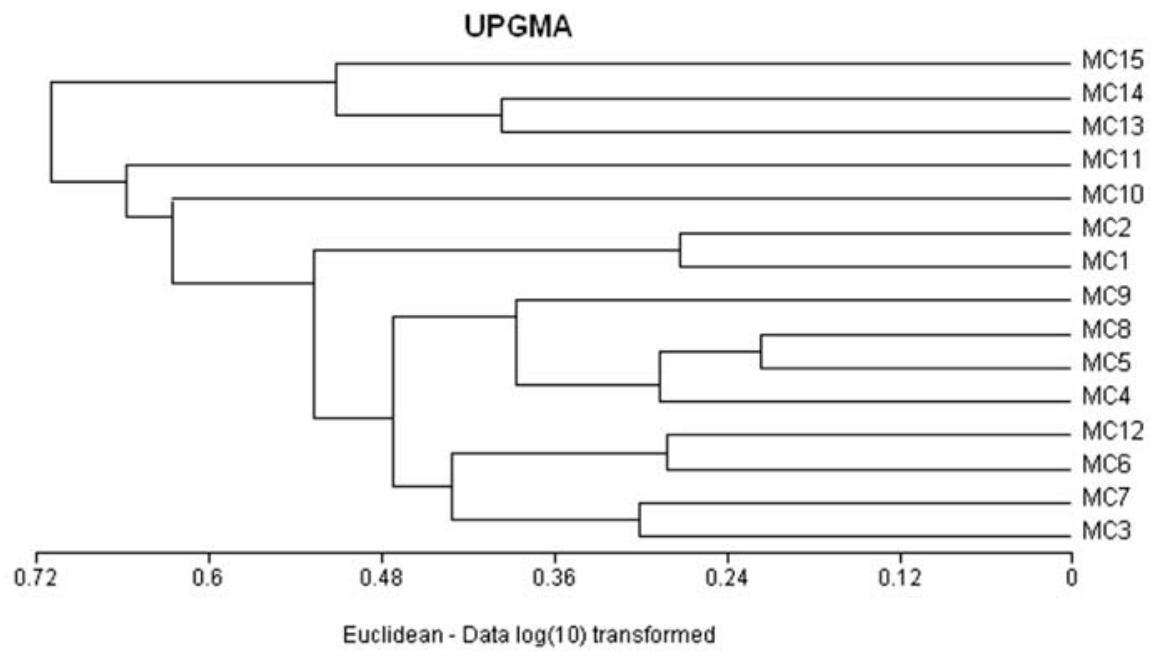

Fig 2. UPGMA Dendogram based on Nutritional Parameters.

PCA Variable Loadings

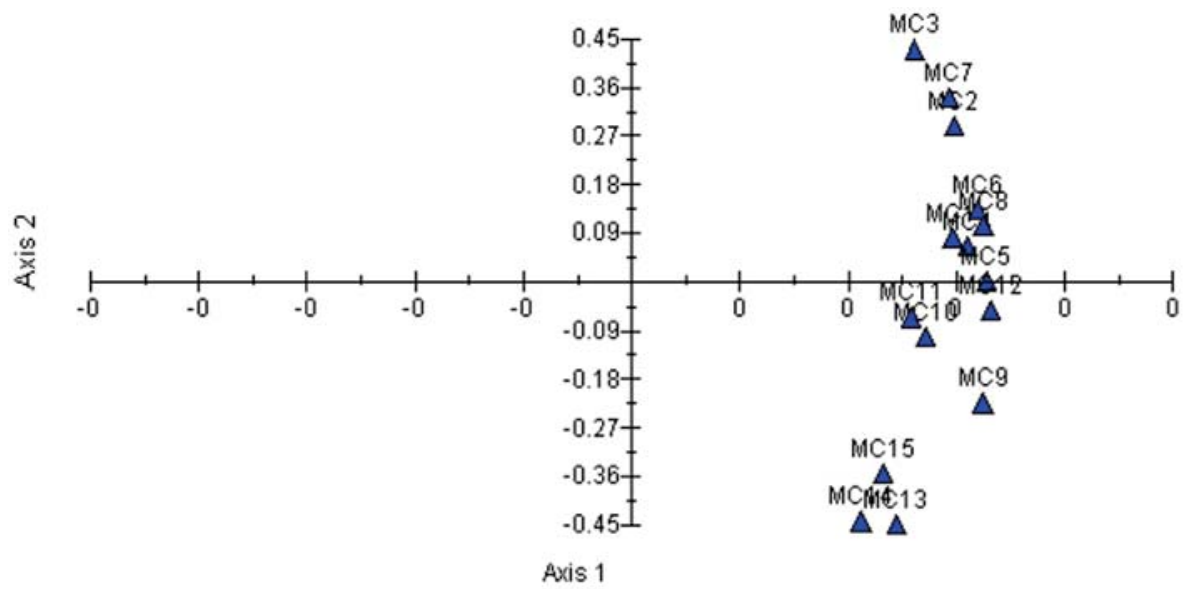

Fig. 3. Scatter Plot Based on Nutritional Characters.

\section{Correlation between fruit traits and nutrient contents in the wild varieties of M.charantia}

The correlation studies between the nutritional characters and fruit traits will be of help in selecting the wild accessions with higher nutrient content for crop improvement programmes. Pearson correlation study among the wild varieties of M.charantia revealed strong negative correlation between fruit traits (fruit weight, diameter, and length) and Vit. $\mathrm{C}$, copper, and calcium indicating the presence of rich nutrient contents in plants with small fruits (Table 4). 
According to Behera et al., (2010), negative correlation was observed between fruit traits (weight, fruit length and diameter) and ascorbic acid content in the cultivars of M.charantia. They suggested that the selection of small fruited cultivars is known to improve the ascorbic acid content. The present study thus recommends the accession MC7 with high vitamin C (69 mg/gm), collected from Thiruvananthapuram district Kerala as the most suitable taxa and can be used to enhance the ascorbic acid content of the cultivated variety. The negative correlation between fruit size and protein was reported at intra specific level in the fruits of Rhamnus alaternus (Izhakiet al. 2002). Correlation between protein content and fruit size observed in the present findings indicates that the wild variety MC2 with small sized fruits can also be preferred for crop improvement. A positive significant correlation between all the four fruit traits and carbohydrate content noticed in the wild varieties indicates that carbohydrate is directly related to the size of the fruit. Significant negative correlation between fruit size and Ca content suggests that small fruits are rich sources of Calcium. Bakare et al. (2010) reported that Ca was the most abundant mineral present in the leaf of M.charantia. The present investigation observed a positive significant correlation between reducing and non-reducing sugar with fruit size and fruit weight, respectively. Markovik et al. (1996) reported a negative correlation between fruit weight and total sugar content in tomato.

The study noticed both positive and negative correlation between fruit traits and the nutritional parameters like total sugar, Vit. $B_{1}$ and $\mathrm{Zn}$,at 0.01 and 0.05 levels indicating the antagonistic interaction between nutrients ( eg: $\mathrm{CHO}$ and vit $\mathrm{E}, \mathrm{Ca}$ and $\mathrm{Mg}$ ). Cecil et al. (1995) pointed out that the interrelationship among fruit nutrients may be due to synergistic and antagonistic interaction between nutrients or due to plant-environment relations. Significant positive correlation existing between $\mathrm{Mg}$ and $\mathrm{Ca}(\mathrm{r}=0.25)$ at 0.05 level suggests that they are closely associated in the metabolic pathways. Such an association was detected by earlier researchers (Garten,1976; Alonso and Herrera, 2001,Izhaki et al. 2002) and Garten (1976) opined that this correlation was probably a consequence of the close association of $\mathrm{Ca}$ and $\mathrm{Mg}$ in metabolism and photosynthesis.

Most of the fruit morphological traits were significantly correlated with each other at 0.01 level too. There was a direct relationship between the nutrient contents and the fruit traits (fruit weight and length together with fruit diameter and clutch size). Behera et al. (2010), opined that the fruit weight had the greatest direct effect on fruit length in the cultivars of bitter gourd. Varitions observed in the nutrient composition in the fruits of the wild accessions in the present investigation may be due to the interaction of the environment and the genotype. Difference in the environmental conditions between plant microsites impressed greater variability on fruit composition than on fruit morphological traits.

\section{CONCLUSION}

The study revealed the superiority of the wild variety, $M$.charantia var. muricata, over the cultivar in terms of nutrient composition. The study recommends the use of the wild accessions, particularly MC10, MC12, MC 2 \& Mc7, the rich sources of nutrients to produce varieties with superior qualities in Momordica breeding programmes. The investigation also emphasized the conservation of the wild varieties for future breeding programme.

\section{ACKNOWLEDGEMENT}

The authors acknowledge the Department of Science and Technology for the financial support and Dr. P.M. Radhamany, Head, Department of Botany, University of Kerala, for providing the facilities. 


\section{REFERENCES}

ABEROUMAND, A. (2010) A comparative study of nutrients and mineral molar ratio of some plant foods with recommended dietary allowances. Advanced Journal of Food Science and Technology 2 (2): 104-108.

ABEROUMAND, A. and S.S. DEOKALA. 2009. Proximate and mineral composition of wild $\operatorname{coco}($ Eulophia create L.) tubers in Iran. Asian Journal of Food Agriculture and Industry 2(02) 203-209.

ALONSO, C. and C.M. HERRERA. 2001. Patterns made of patterns: variation and covariation of leaf nutrient concentrations within and between populations of Prunus mahaleb. NewPhytologist150 629-640.

BAKARE, R.I., O.A. MAGBAGBEOLA, A.I. Akinwande, and O.W. Okunowo. 2010. Nutritional and chemical evaluation of Momordica charantia. Journal of Medicinal Plant Research4(21):2189-2193.

BEHERA, T. K. 2004. Heterosis in bitter gourd. In Hybrid vegetable development.eds. P. K. Singh, S. H.Dasgupta and S. K. Tripathi. Haworth Press, New York.

BEHERA, T. K., S. BEHERA, L.K. BHARATHI, K. JOSEPH JOHN, W.S. PHILIPP, and E.S. JOHN. 2010. Bitter gourd: Botany, horticulture, breeding. Horticultural Reviews 37:101-141.

BHARATHI, L.K., A.D. MUNSHI, T.K. BEHERA, VINOD, K. JOSEPH JOHN, A.B. DAS, K. V. BHAT, and A.S. SIDHU. 2012. Production and preliminary characterization of inter-specific hybrids derived from Momordica species. Current Science 103(2):178-186.

CECIL, J.S., G.E. BARTH, N.A. MAIER, W.L. CHVYL, and M. N. BARTESKO. 1995. Leaf chemical composition and nutrient removal by stem of Leucadendron cvSilvan Red and Safari Sunset. Australian Journal of Experimental Agriculture 35: 275-283.

CORLETT, R. T. 1996. Characteristics of vertebrate- dispersed fruits in Hong Kong. Journal of Tropical Ecology12:819-833.

DEBUSSCHE, M., J. CORTEZ, and I. RIMBAULT. 1987. Variation in fleshy fruit composition in the Mediterranean region: the importance of ripening season, life form, fruit type and geographical distribution. Oikos 49: 244-252.

DESAI, U. T., and A.M. MUSMADE. 1998. Pumpkins, squashes and gourds 273-298. In Handbook of vegetable science and technology: production, composition, storage and processing. eds. D. K. Salunkhe and S. S. Kadam Marcel Dekker, New York.

DEY, S.S., T.K. BEHERA, and C. KAUR. (2005-2006). Genetic variability in ascorbic acid and carotenoids content in Indian bitter gourd (Momordica charantiaL.) germplasm. Cucurbit Genetics Cooperative Report 28-29: 91-93.

EDMONS, J., and J. CHWEYA. 1995. Black nightshades, Solanumnigrum L. and related species in Promoting the conservation and use of under utilized and neglected crops. 221-234. Taylor and Francis London.

EROMOSELE, I.C., C.O. EROMOSELE, and M. KUZHKUZHA. 1991. Evaluation of mineral elements and ascorbic acid contents in fruits of some wild plants. Plant Foods for Human Nutrition.(41)151-154.

FREIBERGER, C.E., D.J. VANDERJAGT, A. PASTUSZYN, R.S. GLEW, G. MOUNKAILA, M. MILLSON, and R.H. GLEW. 1998.Nutrient content of the edible leaves of seven wild plants from Niger. Plant Foods for Human Nutrition. 53(1):5769.

GARTEN, C.T. 1976. Correlation between concentration of elements in Plants. Nature 261: 686-688.

HARRIS, L. J., and S.N. RAY. 1935. Determination of plasma ascorbic acid by 2,6dichlorophenol indophenol titration. Lancet 1:462.

HEDGE, J.E., and B.T. HOFRIETER. 1962. In: Carbohydrate chemistry 17. eds. R.L.Whistler and J. N. Be Miller. Academic Press ,New York. 
HERRERA, C. M. 1987. Vertebrate- dispersed plants of Iberian Peninsula: a study of fruit characteristics. Ecological Monographs 57: 305-331.

IZHAKI, I., E. TSAHAR, I. PAULY, and J. FRIEDMAN. 2002. Within population variation and interrelationship between morphology, nutritional content and secondary compounds of Rhamnus alaterus fruits. New Phytologist 156:217-223

JORDANO, P.1984. Seed weight variation and differential avian dispersal in blackberries Rubus ulmifolius. Oikos 43:149-153.

JOSEPH J.K., and V.T.ANTONY. 2010. A taxonomic revision of the genus Momordica L. (Cucurbitaceae) in India. Ind. J. Plant Genet. Res. 23(2): 172-184.

KALE, A.A., S.R. GADAKH, and R.N. ADSULE. 1991. Physico-chemical characteristics of improved varieties of bittergourd (Momordica charantiaL.) Maharashtra Journal of Horticulture 5:56-59.

KENDRICK, L. M., X.Y. MEI, and N.K. BHATTARAI. 2004. Allozyme, morphological and nutritional analysis bearing on the domestication of Momordica charantiaL. (Cucurbitaceae). Economic Botany 58(3): 435-455.

LOWERY, O.H., N.J. ROSEBROUGH, L.A. FAN, and R.J. RANDALL. 1951. Protein measurement with the Folin-Phenol reagent. Journal of Biological Chemistry 193:262275.

MAHADKAR, S., S. VALVI, and V. RATHOD. 2012.Nutritional assessment of some selected wild edible plants as a good source of mineral. Asian Journal of Plant Science Research 2 (4):468-472.

MAHAPATRA, A. K., S. MISHRA, U.C. BASAK, and P.C. PANDA. 2012.Nutrient analysis of some selected wild edible fruits of deciduous forests of India: an explorative study towards non conventional bio-nutrition. Advanced Journal of Food Science and Technology 4(1): 15-21.

MARKOVIC, Z., J. ZDRAVKOVIC, and M. DAMJANOVIC. 1996. Correlation between the morphological characteristics and the biochemical components of tomato fruit quality. Acta Horticulture (ISHS) 462: 151-156.

MILLER, G. I. 1972.Use of dinitrosalicylic acid reagent for determination of reducing sugars. Analytical Chemistry 31:426.

MINIRAJ, N., K.P. PRASANNA, and K.V. PETER. 1993.Bitter gourd Momordica spp.In Genetic improvement of vegetable plants.eds. G.Kalloo and B.O. Bergh.Pergamon Press, Oxford,UK.

MURUGKAR, D. A., and G. SUBBULAKSHMI. 2005. Nutritive values of wild edible fruits, berries, nuts, roots and spices consumed by the Khasi tribes of India. Ecology and Food Nutrition 44 (3): 207-223.

OBESO, J.R. and C.M. HERRERA. 1994. Inter and intra specific variation in fruit traits in co occurring vertebrate dispersed plants. International Journal of Plant Science 155: 382-387.

OKWU, D. E. 2005. Phytochemicals, vitamins, and mineral contents of two Nigerian medicinal plants .International Journal of Molecular Medicine and Advanced Science 1(4): 375-381.

RANGANA, S.C. 1979. Manual of Analysis of Fruit and Vegetable Products. Tata McGraw Hill Publishing Company Limited, New Delhi.

REYES, M.E.C., B.H. GILDEMACHER, and G.J. JANSEN. 1994. Momordica L.pp.206210 In: Plant resources of South-East Asia: Vegetables. eds. J.S. Siemonsoma and K. Piluekaeds. Pudoc scientific publishers, Wageningen, the Netherlands.

SINGH, D., V. BAHADUR, D.B. SINGH, and G. GHOSH. 2009. Spine gourd ( Momordica dioca) : An underutilized vegetable with high nutritional and medicinal values . Acta Horticulturae (ISHS) 809: 241-248.

ULLAH, M., F. KARIMCHY, S.K. SARKAR, M.K. ISLAM, and N. ABSAR. 2011. Nutrient and phytochemical analysis of four varieties of bitter gourd (Momordica charantia) grown in Chittagong Hill Tracts, Bangladesh. Asian Journal of Agricultural Research:1-5. 
VOGEL, A.I. 1962. In: A text-book of quantitative inorganic analysis (including elementary instrumental analysis). 3rd Ed. Longmans, Green, London.

WILLS, R.B.H., A.W.K WONG, and F.M. SCRIVEN. Greenfield, H.1984. Nutrient composition of Chinese vegetables. Journal of Agriculture and Food Chemistry.32(2):413416.

YUWAI, K.E., K.S. RAO, J.C. KALUWIN, G.P. JONES, and D.E. RIVETTS. 1991. Chemical composition of Momordica charantiaL. Fruits. Journal of Agriculture and Food Chemistry 39: 1782-1763. 